This is an electronic reprint of the original article. This reprint may differ from the original in pagination and typographic detail.

Author(s): Pitkänen, Olli

Title: Re-enchantment and contemporary demonology

Year: $\quad 2017$

Version:

Please cite the original version:

Pitkänen, O. (2017). Re-enchantment and contemporary demonology. In B. W. McCraw, \& R. Arp (Eds.), Philosophical Approaches to Demonology (pp. 209-222). Routledge. Routledge Studies in the Philosophy of Religion.

All material supplied via JYX is protected by copyright and other intellectual property rights, and duplication or sale of all or part of any of the repository collections is not permitted, except that material may be duplicated by you for your research use or educational purposes in electronic or print form. You must obtain permission for any other use. Electronic or print copies may not be offered, whether for sale or otherwise to anyone who is not an authorised user. 


\section{Re-Enchantment and Contemporary Demonology}

"Occultism" and "esotericism" are terms everyone is familiar with, but few people actually have

any precise definition for them if asked. Before all, a strong disregarding attitude has reigned both

within the academic world and the general public towards anything that is conceived as "occult".

According to the leading scholar in the field, Wouter Hanegraaff, "superstition", "magic", and

"occultism" are generally seen largely equivalent. However, when it comes to proper academic

research:

Each of them has a very long and complex history, and none of them should be used innocently or naively on the assumption that 'everyone knows what is meant': the fact is that almost nobody does, although most people think they do. [...] Although terms 'superstition', 'magic', and 'occult' have long histories, they were essentially reinvented during the period of the Enlightenment, in such a manner that they could serve to demarcate 'the Other of science and rationality'. (Hanegraaff 2013, 157.)

Hanegraaff's main argument is that while the basic building blocks of the current popular

"disenchanted" scientific worldview were established during the Enlightenment, this could happen

only by juxtaposing the rising new paradigm with something that was conceived as foregone,

namely "the occult":

Understood in terms of disenchantment, the core identity of modern post-Enlightenment society and its appointed representatives (such as, notably, academics) requires and presupposes a negative counter-category consisting of currents, practices and ideas that refuse to accept the disappearance of incalculable mystery from the world. Moreover, the new science and post-Enlightenment society define themselves as 'modern' by way of contrast with any appeal to the authority of 'ancient wisdom'. This combination makes the domain nowadays known as 'Western esotericism' into much more than just a collection of currents and ideas that happen to have been neglected or overlooked: rather, by being conceptualized as 'the Other of science and rationality' it functions as the dark canvas of presumed backwardness, ignorance or irrationality that modernity needs in order to paint the outlines of its own identity 
in shining colors of light and truth. In short: modern identities imply the occult. (Hanegraaff 2013, 254.)

If Hanegraaff is correct, it is quite easy to understand why until recently neutral historical research on esotericism has been very scarce. Everything explicitly relating to "the occult" has been dumped into "a conceptual waste-basket for 'rejected knowledge', and it has kept functioning as the academy's radical 'Other' to the present day" (Hanegraaff 2013, 221). Neutral in-depth study would show that actually esoteric traditions contain coherent alternative philosophical views, which cannot be dismissed at once as irrational nonsense. Even though notes such as "even Newton still practiced alchemy" are quite common in all branches of science, the intention of this kind of notes is usually only to emphasize that "even the wisest men are products of their own time", which, in this context, is actually to say that esotericism can at best represent a pre-stage of science and modern philosophy.

The point is well demonstrated by the famous philosopher of science Paul Feyerabend who struck his eye on a statement by 186 leading professors of various fields whose sole point was to dismiss astrology as a pseudoscience. In Feyerabend's view the statement itself has a dogmatic religious tone in it and uses the scientific status of the signees in authoritative manner that is completely opposite to good scientific practice - taking seriously the controversial claim, forming a hypothesis based on it and testing it carefully. Feyerabend $(1982,23)$ also points out that when BBC asked several of the signees to an interview about astrology they refused referring to the fact that they actually knew nothing about astrology. All in all, Feyerabend $(1982,19-20)$ provocatively deems Malleus Maleficarum, the famous medieval manual for witch-hunting, superior to the statement in terms of scientific methodology. 
In this kind of intellectual climate, it is not that surprising that proper academic research on esotericism began not until early 90's by Antoine Faivre's pioneering impulse (Hanegraaff 2013, 352). Faivre (1994, 10-14) attempted to define esotericism constructively as a "form of thought" by four central elements:

1.) Correspondences. The idea of correspondences is quite exhaustively expressed in the Hermetic axiom "as above, so below". In esoteric form of thought mechanical physical interaction between things, studied by modern natural science, is of secondary importance. Rather, everything in nature is thought to correspond in endlessly complex ways to eternal supersensuous archetypes such as the seven planets or the four elements. Ancient sciences such as astrology, and magical thinking in general is based on this idea of visible nature as the outer manifestation of the archetypical supersensuous reality.

2.) Living nature. Unlike the predominant view since Descartes would have it, esotericism does not see any abrupt distinction between human beings and other nature, or between organic and inorganic nature. Rather than conceiving life and consciousness ultimately as matter, the idea of "dead matter" is completely foreign to esotericism. According to this form of thought, the so called raw matter is already living "in a lesser degree".

3.) Imagination and mediations. The basic theoretical framework for esoteric praxis, correspondences, requires free-floating imagination instead of mere syllogistic reasoning. However, imagination in this context is not only a psychological mediation between senses and reason but rather mediation between human and divine understanding. Esoteric form of thought has its own conception of knowledge, Gnosis, which does not consist in testing empirical well-defined propositional hypotheses (knowledge of facts) but in gradual process of becoming one with what is known. 
4.) Experience of transmutation. Relating to the mediating role of imagination, the fourth central element of esotericism is the idea of transmutation or metamorphosis of one's whole being, not only quantitative development of fixed pre-ordained attributes. At the most large scale this view results in the idea of evolution from mineral kingdom to plants, animals, man, and finally gods. ${ }^{\text {ii }}$

It is important to notice that Faivre's definition of esotericism as a form of thought means that esotericism is not properly speaking a philosophy; it is its own form of thought that does not properly fit in the category of philosophical or religious forms of thought as they are usually understood (even though it obviously verges both at some points).iii Since the 90 's the unique nature of esotericism compared to mainstream Western thinking has begun to gain some serious attention. Hanegraaff sums the situation in the time of writing his magnum opus on esotericism, Esotericism and the Academy, as follows:

Over the past twenty years, the situation has begun to improve. At the time when I began exploring it, there was exactly one academic chair devoted to this continent of learning as a whole, and no university program where students could study it as part of a regular curriculum. At the time of writing, there are at least three, all in Europe: still a very modest number, especially if one considers the vastness of the terrain, but an encouraging beginning that promises more to come. Several academic journals and learned societies, countless international conferences, and great number of articles and books demonstrate that what used to be, arguably, the single largest stretch of terra incognita in modern academic research is now attracting scholars in ever greater numbers. They even seem to have agreed about what to call it: Western esotericism. (Hanegraaff 2013, 2-3.)

The rising interest to esotericism is also evidently not limited to academic research, but rather the increasing academic scholarship may reflect a wider cultural turn. Christopher Partridge argues in his monumental two-volume work The Re-Enchantment of the West that while Max Weber's idea of "disenchantment" has usually been thought as an essential characteristic of modernity, today it seems instead that there is a growing "re-enchantment" of Western culture going on. By extensive 
analyses of popular culture, general interest in Eastern spirituality, "eco-enchantment", holistic medicine, UFO fascination and eschatological apocalyptic currents etc. Partridge sees contemporary modernity in terms of increasing alternative spirituality rather than proceeding secularization. While classical institutional religions are generally losing their significance in the Western world, people are not necessarily becoming more irreligious but rather new more subjective forms of spirituality are emerging. (Partridge 2004, 1-5, 185-188.)

\section{Philosophy and esotericism: the case of Schelling}

Even though the academic world has recently paid proper attention both to serious esoteric traditions and to popular interest in "the occult", one thing is almost entirely lacking. To my knowledge there doesn't exist any significant body of contemporary philosophical research on esotericism. However, there are some signs that this will change in future. A good example can be found from my own field of expertise, that is, study of German idealism. The traditional $20^{\text {th }}$ century narrative on German idealism presents Hegel as the unequivocal culmination of the tradition, after whom the idealistic project collapsed in its own grandiose. During last few decades this view has been severely challenged by the discovery that Hegel's predecessor F.W.J. Schelling had already offered essentially the same critiques of Hegel that have usually been associated with Heidegger and later postmodernists (and recent "anti-postmodern" movements such as speculative realism). iv For example according to the leading American Schelling-scholar Jason Wirth, "Schelling is better construed not as the already sublimated objective counterpart to Fichte, a loopy mystic, or as an antiquated theologian but rather as the belated contemporary to thinkers like Heidegger, Derrida, Bataille, Irigaray, Foucault, Deleuze, Levinas, and many others" (Wirth 2005, 6). 
My argument, on the contrary, is that in the end Schelling may be a hot character today not despite he was also a "loopy mystic" but ultimately because of that. Before Schelling was found again as a relevant philosopher to discuss outside mainly historical interests it was often emphasized that Schelling's most significant influences included purely esoteric thinkers such as, most notably, the theosophist Jacob Boehme (McGrath 2012, 74-75). Today instead S.J. McGrath is one of the very few commentators that pay significant attention to Schelling's esoteric influences. McGrath claims that the revolutionary nature of the central ideas of Schelling's middle period works Philosophical Inquiries into the Nature of Human Freedom and The Ages of the World actually stems from the continuum of esoteric thought, which had been rejected by academy for a good while already in Schelling's time not even to mention late $20^{\text {th }}$ century philosophy. Unlike an explicitly esoteric figure such as Boehme Schelling, who primarily represents German idealism - a respectable even if in some respects outmoded current - could become seriously re-thought as a "belated contemporary". The consciousness of the significance of esotericism to Schelling's revolutionary ideas has not of course completely vanished. For example Slavoj Žižek puts the matter in the following way:

Therein consists the unique intermediate position of Schelling, his double-noncontemporaneity to his own time: he belongs to three discursive domains - he simultaneously, as it were, speaks three languages: the language of speculative idealism; the language of anthropomorphicmystical theosophy; the post-idealist language of contingency and finitude. The paradox, of course, is that it was his very 'regression' from pure philosophical idealism to pre-modern theosophical problematic which enabled him to overtake modernity itself. (Žižek 2007, 8.)

Žižek recognizes that Schelling's esoteric influences play a crucial role in why he has again become an interesting thinker, but Žižek evidently takes for granted that the core ideas of esotericism cannot be taken seriously today, allegedly because of their "anthropomorphism". The term "anthropomorphism", however, is based on contestable metaphysical assumptions, as I will argue. 
According to McGrath $(2012,22)$, the most central of Faivre's four characteristics of esotericism is "living nature", the idea that there are no absolute distinctions between rational-conscious, organic, and inorganic nature but nature as a whole is a living organism. This idea is the crux that makes esoteric thought intelligible. The idea of living nature, which largely equals to "anthropomorphism", is also the core of Schelling's philosophy throughout the highly diverse phases of his career (McGrath 2012, 23).

The accusation of anthropomorphism is essentially a claim that human characteristics such as will and intelligence are attributed to nature. It is argued that although this kind of thinking was completely logical in pre-modern times, it is against our contemporary scientific understanding of nature. However, the idea of living nature might precisely be the central factor behind the current Schelling-renaissance. Reductive physicalism is not very popular today for well-known reasons. Yet it is not unproblematic to conceive consciousness as emergent product of physical nature. Even if the idea of emergence is taken for granted, it is notoriously hard to decide where to draw the line between "living" and "dead" nature. The idea of living nature certainly has the advantage that it avoids both the problems of physicalism and emergent naturalism.

If one accepts Hanegraaff's sociological argument of esotericism as "the Other" of modern thinking, it is now possible to argue why contemporary Schelling-scholars keep quiet on Schelling's esoteric influences: Schelling's idea of living nature has something important to offer, but at the same time this offering is the core of rejected esotericism that is conceived as hopelessly "anthropomorphic". It is usually taken for granted that Schelling's idea of living nature cannot be taken seriously as such. Instead, contemporary commentators such as Wolfgang Hogrebe, Žižek and recently Markus Gabriel attempt to formalize Schelling's metaphysics thereby saving the 
innovative elements in it while disregarding its anthropomorphism. It is possible that such a strategy succeeds in a plausible way, but it is highly doubtfulv .

Some contemporary front line analytical philosophers, for example Thomas Nagel $(2014,66)$, Galen Strawson (2008, 53-57) and David Chalmers (2010, 138-139), take seriously and more or less advocate panpsychism, a view that everything in nature includes mental as well as physical characteristics, that is, essentially the idea of living nature. Even though their arguments are careful and their style of writing is not provocative they have faced lots of disapproval that far exceeds ordinary academic criticism. For example Strawson $(2008,10)$ has "been almost uniformly unsuccessful in submitting papers to journals" even though he certainly is a qualified philosopher and handles the academic writing conventions. It is not after all unheard of that the scientific community is for a good while unwilling to take seriously a fully plausible idea simply because of collective emotional resistance. If this is not the case one has to give an actual argument why the idea of living nature is so evidently incompatible with our current scientific knowledge that it does not deserve to be taken seriously at all.

\section{Living nature and modern thinking}

If one asks what kind of thinking is not conceived anthropomorphic, it is natural to begin from

Descartes who is characteristically taken as a foundational figure of modern mainstream thought. Before Descartes philosophers had various complex metaphysical and theological disputes about the nature of God, soul, angels etc. Descartes famously questioned the methodological legitimacy of any such knowledge. He saw it necessary to lay new foundation to philosophy by questioning everything one possibly can question. The only thing he found impossible to question was the 
existence of the questioner itself. And because the existence of my thinking self does not directly require the existence of anything material, the material world (if it exists) consists of a completely different substance.

The second character who unequivocally delineates modern philosophy in general is Immanuel Kant. After his "critical turn" Kant famously argued that no idea alone, however inescapable in its presence to mind, can prove that the idea in question corresponds to anything in reality. According to Kant, before making any knowledge claims we must first ask whether it possible to gain the type of knowledge we are searching for. In the Transcendental Aesthetic and Transcendental Analytic sections of his Critique of Pure Reason he attempts to show that all our possible experiences are formed as fusion of our sensuous "forms of our intuition" (space and time) and discursive "categories of understanding" (cause and effect etc.) According to Kant, any knowledge beyond the boundaries of possible experiences is impossible, and so all the traditional metaphysical questions are misguided when understood as questions of fact.

Despite the huge differences of Kant and Descartes they have one common point of departure that has defined modern thinking up to this day: taking the thinking human subject as the foundation for all philosophical thinking. It follows that nature is defined from the start as passive object that the active subject confronts. The essential difference is only that for Descartes the human subject perceives the order of nature while for Kant it is also structured by human subjectivity. Yet nothing is more obvious than the fact that humans are also a part of nature and our active subjectivity is somehow produced by the allegedly passive nature. According to McGrath this duality between nature and humanity is the point of departure in modern philosophy in general: 
Modern philosophy cleaves being into two opposed structures, subject and object, without indicating why the distinction is necessary or showing what makes it possible. The Cartesian systems of philosophy, Descartes', Kant's, and Fichte's, remain stuck in this unexplained duality, where all that is said is that subject is not object, even if it is never without it, a point we will formalize thus: $\mathrm{S} \neq 0$. (McGrath 2012, 24.)

If the absolute duality of subject and object is the starting point that defines modern thinking in general, it equals to rejecting the idea of living nature from the start. Thinking is in the first place conceived as something completely other than nature which is the object of thought. But the duality of subject and object can quite plausibly be approached from a completely different angle:

Two can only be essentially opposed if they share some common ground which cannot be reduced to either one of them. The idea here is that opposition is not only disidentification, it is also a mode of relation: the one is related to its other as to that which it is not, and all such relations are only possible on the supposition of commonality. Thus the large can be opposed to the small because both are possible qualities of a body, which is in itself neither large nor small. Or in a more Schellingian key, mind can be opposed to matter because both are possible forms of some unknown order of being which is in itself neither mental nor material. [... ] Schelling's argument is that the subject-object distinction presupposes a common ground of the subject and the object which is neither subject or object: $(S \neq O) / X . X$ is indifferent to but not identical with $\mathrm{S}$ and $\mathrm{O}$, therefore $\mathrm{X}$ can ground both $\mathrm{S}$ and $\mathrm{O}$. Thus is the oppositional relation of $S$ and $O$ explained even if $X$ remains inscrutably mysterious - in fact its inscrutability is essential to its explanatory power. (McGrath 2012, 24-25.)

Schelling and esoteric thought in general begin from what McGrath $(2012,23)$ calls neoplatonic logic: neither the subject nor the object can be an absolute starting point for philosophy but they must have a common ground that unites both. There is something minimally subjective in nature, and, on the other hand, as also modern science has empirically shown, subjectivity is at the same time manifested in objective physical processes.

When it comes to the accusation of anthropomorphism, it should be looked more clearly what the idea of living nature is about. When esotericists, Schelling and today's panpsychists argue that everything in nature is conscious to a minimal degree, they are not claiming that nature is 
conscious in the same way as humans are. They merely address that there are no absolute leaps in nature between what is conscious and what is not. Given that human consciousness evidently exists as a part of nature, nature must have somehow been able to produce it. If there is an absolute gulf (at least) between human and inorganic nature, the only way to explain the emergence of the former from the latter is to assume some kind of inconceivable leap in the working of nature. ${ }^{\mathrm{vi}}$ The view of living nature instead begins from the idea that no such gulf exists; that consciousness increases gradually towards human beings, and all nature has minimally an element of proto-consciousness in it. This kind of metaphysics do not contradict the causal explanations of science but merely state that causal explaining is not the ultimate description of reality but that it actually needs a ground to explain how it is possible that merely causal nature produces something that feels, wills and is in any sense conscious in the first place. It may quite well be argued that it is mainstream modern thinking that is anthropocentric since it assumes that scientific human praxis describes the ultimate truth about nature.

\section{Demonology today}

The rejection of the idea of living nature includes as an important element the rejection of demonology. As Partridge $(2005,207)$ notes, the belief in disembodied spirits has been a common cultural element across the world through history. According to Hanegraaff $(2013,254)$, it is precisely the outright denial of this kind of beliefs that constitutes the modern rationality from the Enlightenment onwards. We may today indeed have enough scientific evidence that spirits do not actually exist in the sense that there would be physical changes in the world that couldn't be causally explained without assuming some extra-causal spiritual influence. It is yet an entirely another matter how much significance this purely theoretical fact carries. The rejection of actual 
demonology as theoretical framework does not by any means imply that our thinking is not implicitly guided by essentially demonological ideas.

Kant $(2003,471)$ himself constantly insisted that in the end theoretical fact claims are always ultimately subordinated to practical interests. Indeed, the main purpose of the critical project was to justify faith in the freedom of will, morality and even Christian God as "postulates of pure practical reason", that is, practically necessary ideas that are not epistemologically justified as fact claims. Kant never developed the idea, but it seems clear that there can also be ideas that are not at least strictly necessary but nevertheless significant. Kant was convinced of the special practical significance of the Christian religion, but his arguments are quite weak at this point. It is hard to see why other metaphysical ideas could not be equally meaningful. My argument in this final chapter will be that esoteric demonology could indeed be more beneficent to humanity than Christian one that is still operative in our cultural landscape even though not usually in an explicit form.

The demonic obviously fascinates masses today even if most people don't believe that demons in fact exist. Demonic imagery in popular films, TV series, books, video games, clothing, music (especially heavy metal) etc. is so common that one does not easily pay any serious attention to the reasons of its appearance. While very few people actually worship the Devil, it is often easy to believe that others do so even to the extent that something analogous to witch hunts takes place in our modern society. In the 80 's and 90's especially the USA but also several other Western countries saw utterly paranoid "satanic panics"; mass movements with professionals such as polices, teachers and psychiatrists involved in claiming that more or less organized Devil worship groups for example kidnap random children and abuse them in their ceremonies (Partridge 2005, 218-221). vii Overall, even though today's spiritual landscape is moving towards a more eclectic and 
monistic direction away from dualistic traditional institutional Christianity, presentation of the demonic derives still from the Christian tradition (Partridge 2005, 277).

According to Partridge $(2005,278)$, the most likely reason for the prevalence of Christian demonology is simply its familiarity compared to for example complex and alien Indian demonologies. In addition to Partridge's thesis, I shall argue that Christian demonology does not fade away easily because Christianity has always hidden its problematic relation to the idea of evil behind simple solutions, and people living in essentially Christian heritage are not often prepared to adopt more complex accounts of evil. While something like the esoteric idea of living nature becomes more and more popular in the West, it is often understood quite shallowly. If the neoplatonic logic behind the idea of living nature is properly understood, one cannot at the same time coherently advocate traditional Western mainstream ideas of evil. The difficult dualism between subject and object or mind and nature in modern Western thinking stems from the Christian tradition, and the dualism between good and evil is follows the same logic inherent in it. Put shortly, the paradox is that evil is something that absolutely should not be, but on the other hand, good gains its value only in opposition to evil, that is, in order for good to be good evil has to exist.

Western thinking has always found the existence of evil utterly problematic. Without the aid of paradoxical neoplatonic logic both traditional mainstream Christianity and secular humanism fluctuate within uncompromising monism and equally uncompromising dualism. The official doctrine of Christianity regarding good and evil has been monistic; a perfect God does not create anything that should not be, and therefore evil is explained as ultimately non-existent. However, practically Christians often take evil to be a real force, independent and opposed to good, which must be fiercely fought against. The same fluctuation applies to secular rationalism. Officially evil 
is usually understood as an expression of condemnation that people use to demonize negative

things they are unable or unwilling to understand; "a holdover from a mythical, Christian

worldview whose time was already past", as Lars Svendsen $(2010,9)$ puts it. Yet, as Russ Shafer-

Landau aptly observes, for example the 11.9 terror strikes exemplified the shallowness of the

official doctrine when it comes to practice:

Whatever happened to good and evil? Prior to September 11, these notions didn't have the currency they once did. They struck many as old-fashioned, as quaint vestiges of less skeptical times. Many preferred to give up on these concepts; others were happy to keep them, so long as the appropriate qualifications were entered. We signaled our hesitations by declaring things right - for me; or wrong - according to my culture. This sort of moral humility wasn't entirely unappealing. But it was unsuited to issuing the kind of condemnations that we sought to express in the wake of the terrorists' destruction. Those who perpetrated the attacks weren't just offending against our point of view. They were offending against the enlightened ethic of any person with a moral conscience. What they did was evil. (Shafer-Landau 2004, vii.)

In his article advocating Schelling's metaphysics of evil Joseph Lawrence puts well a similar argument:

The denial of evil assumes two forms. In times of peace, it is the optimistic assumption that evil is little more than an unfortunate residue of our animal heritage, the survival of aggressive instincts that can ultimately be overcome by reason. In times of crisis, it is taken more seriously as a demonic force, but in a way that still allows us to speak of denial: for the demonic is viewed as abiding only in the other. In fact, it is the very assumption that we ourselves are without evil that generates the conclusion that our enemies must be demonic: who else would oppose anyone as good as we are? (Lawrence 2004, 170.)

Even more than the other central dualisms of modern Western philosophy the dualism of good and evil is re-assessed in Schelling's Freedom Essay. The conceptual distinction by which Schelling grounds all the essential problematic dualisms in modern philosophy (mind and nature, good and evil, freedom and necessity, God and beings etc.) is that between "existence" and its "ground". By existence Schelling means the whole of nature (which he equates with God) insofar as it can be comprehended rationally. However, in order that anything properly new can appear in God, things 
"have to carry on this becoming on a basis different from him" (Schelling 1992, 33). But because God is everything, "this contradiction can only be solved by things having their basis in that within God which is not God himself, i.e. in that which is the basis of his existence" (Schelling 1992, 33). This basis is the ground, which Schelling understands as the "incomprehensible basis of reality in things, the irreducible remainder which cannot be resolved into reason by the greatest exertion but always remains in the depths" (Schelling 1992, 34). Schelling's argument is that not even God's infinite reason can fully map itself as if from beyond. After all, it seems evident that order can be understood only against the idea of chaos. But Schelling does not conceive the ground merely as a conceptual necessity. In order to be living God as the teleological order of nature God can never actualize himself as fully rational but blind craving always remains in his ground. God's will as an inseparable union of rational order (will for the other) and the chaotic blind craving (will for self) must in their turn be understood against a completely indifferent will, a will that wills nothing (McGrath 2012, 146).

When this neoplatonic logic is applied to the distinction between good and evil, it is possible to retain the sense of objective moral values without creating an absolute gulf between these opposites or reducing evil away, which would result into the above mentioned problems of mainstream Christian and secular views on the nature of evil. Like inorganic nature contains a minimally subjective element in it and the human mind likewise an objective element, even a perfectly good will retains also evil in itself as an energizing potential for the good.

\section{Conclusion}


The point of departure for my argument has been Christopher Partridge's re-enchantment thesis: both the Christian tradition and the Enlightenment rationalism that followed it are slowly but steadily giving space to new types of spirituality that emphasize a holistic unity of humanity and nature. Yet when it comes to evil, either in real life or in art and fiction, people usually rely, implicitly if not explicitly, on Christian demonology that completely separates good and evil. Now when thinker such as Schelling has gone through a renaissance, the time should be ripe to admit that actually his "revolutionary" ideas about nature or good and evil are in fact nothing new: Schelling draws heavily from alchemy, Kabbalah and theosophy, and his central ideas have been basic building blocks of these esoteric currents for centuries but they have not been recognized neither in the Middle Ages and the Reneissance (because of theological orthodoxy) nor during the Enlightenment and later modernity (because of the spirit of Christianity in secular form). But the more effort we put at thorough rational arguments and explaining, the more a fundamental paradox behind the whole system raises its head. If the structure of existence itself happens to be paradoxical, analogous and "mystical" thinking represented by esotericism could possibly offer much to our time. It doesn't mean that rationality should be abandoned altogether or that facts found by modern science should be denied.

Especially the reality of evil has proven to be problematic for the tradition of mainstream Western thinking. Now when thinker such as Schelling has been acknowledged as someone who could offer resources to deal with the inevitable paradox the idea of evil is bound to, the next step should be to study without prejudices the sources where Schelling's insights spring. The facts that alchemy is not plausible from the empirical viewpoint in the light of contemporary science or that demons do not literally exist, affect very little to what practical significance rejected esotericism and its demonologies could offer today. 


\section{References:}

Bok, Bart and Lawrence Jerome and Paul Kurtz. 1982. "Objection to Astrology - A Statement by 186 Leading Scientists". In Philosophy of Science and the Occult, ed. Patrick Grim, 14-18. USA: State University of New York Press.

Chalmers, David. 2010. The Character of Consciousness. USA: Oxford University Press.

Faivre, Antoine. 1994. Access to Western Esotericism. USA: State University of New York Press.

Feyerabend, Paul. 1982. "The Strange Case of Astrology". In Philosophy of Science and the Occult, ed. Patrick Grim, 1923. USA: State University of New York Press.

Grim, Patrick, ed. 1982. Philosophy of Science and the Occult. USA: State University of New York Press.

Hanegraaff, Wouter. 2013. Esotericism and the Academy - Rejected Knowledge in Western Culture. Cambridge: Cambridge University Press.

Kant, Immanuel. 2003. Critique of Pure Reason. Translated by J.M.D Meiklejohn. USA: Dover Publications.

Lawrence, Joseph. 2004. "Schelling's Metaphysics of Evil" in The New Schelling, 167-189. Edited by Norman, Judith and Alistair Welchman. Great Britain: Continuum.

Lewis, James and Jesper Petersen, eds. 2008. The Encyclopedic Sourcebook of Satanism. USA: Prometheus Books.

McGrath, S.J. 2012. The Dark Ground of Spirit - Schelling and the Unconscious. Great Britain: Routledge.

Nagel, Thomas. 2014. Mieli ja kosmos - Miksi materialistis-darwinistinen luontokäsitys on lähes varmasti epätosi. Translated by Lauri Snellman. Tallinn: Basam Books.

Norman, Judith and Alistair Welchman, eds. 2004. The New Schelling. Great Britain: Continuum.

Ostaric, Lara, ed. 2014. Interpreting Schelling - Critical Essays. United Kingdom: Cambridge University Press.

Partridge, Christopher. 2004. The Re-Enchantment of the West - Alternative Spiritualities, Sacralization, Popular Culture and Occulture: Volume 1. Great Britain: Continuum.

Partridge, Christopher. 2005. The Re-Enchantment of the West - Alternative Spiritualities, Sacralization, Popular Culture and Occulture: Volume 2. Great Britain: Continuum.

Schelling, Friedrich. 1992. Philosophical Inquiries into the Nature of Human Freedom. Translated by James Gutmann. USA: Open Court Publications.

Shafer-Landau, Russ. 2004. Whatever Happened to Good and Evil?. USA: Oxford University Press.

Strawson, Galen. 2008. Real Materialism and Other Essays. Wiltshire: Clarendon Press.

Svendsen, Lars. 2010. A Philosophy of Evil. USA: Dalkey Archive Press.

Wirth, Jason, ed. 2005. Schelling Now - Contemporary Readings. USA: Indiana University Press.

Wirth, Jason. 2005. "Introduction: Schelling now" in Schelling Now - Contemporary Readings, 1 -12. Edited by Jason Wirth. USA: Indiana University Press. 
Žižek, Slavoj. 2007. The Indivisible Remainder - On Schelling and Related Matters. United Kingdom: Verso.

1.) Italics are always from the original text unless otherwise mentioned.

2.) Faivre $(1994,14-15)$ also adds two "relative" characteristics that are not necessary in categorizing a current as esoteric but which are very common. "The praxis of concordance" means the belief that all various esoteric traditions share common "perennial wisdom" that cannot be presented in words, and because of this there are apparently different teachings in different traditions. "Transmission" means that this wisdom is preserved in initiatory chains from master to pupil.

3.) Unlike religion, esotericism does not emphasize faith but knowledge. However, unlike philosophy, in seeking knowledge esotericism does not always respect the limits of rational argumentation but it conceives knowledge more subjectively, which leads to the idea that an "initiated" may potentially possess "higher knowledge" that is entirely unintelligible to most humans.

4.) See especially Wirth 2005, Norman and Welchman 2004, and Ostaric 2014.

5.) McGrath argues that the idea of living nature cannot be fully formalized for in such a formalization precisely the most important elements of Schelling's thought are lost: "Notwithstanding the accuracy of Hogrebe's and Gabriel's analysis of Schellingian logic, the formalistic reading of the middle Schelling is an all too common imposition of late twentieth-century presuppositions (atheism, eliminative materialism, dysteleology) onto a figure who would have opposed them in every way. These presuppositions act as a filter, sifting through exactly that in Schelling which we find most difficult to understand, and extracting from his multi-dimentional work a modicum of philosophy which agrees with our own convictions. Lost in the formalization is not only the theology but also the specifically volitional aspect of the potencies. What Hogrebe and Gabriel flatten into pronominal and predicative being are, according to Schelling, specific directions of will, vectors of volition or desire; the potencies are not merely structural features of language but basic elements of nature." (McGrath 2012, 123.)

6.) The point is that although it may be possible to explain causally what is required for consciousness to emerge in the brain, no possible causal explanation can reach what it is like to be conscious. Causal explaining cannot present consciousness and the allegedly "blind" nature as an intelligible continuum.

7.) More about this phenomenon in great detail in Lewis and Peterson 2008. 